\title{
CHARACTERIZATION AND DEGRADATION STATE OF THE TRAILS IN CAPARAÓ NATIONAL PARK
}

\author{
Marcello Pinto de Almeida ${ }^{*}$, Gumercindo Souza Lima², Sebastião Venâncio Martins ${ }^{3}$, Gínia César Bontempo ${ }^{4}$ \\ ${ }^{1 *}$ Federal University of Viçosa, Postgraduate Program in Forest Science, Viçosa, Minas Gerais, Brazil - marcello.efl@gmail.com \\ ${ }^{2}$ Federal University of Viçosa, Forest Engineering Department, Viçosa, Minas Gerais, Brazil - gumercindo.ufv@ gmail.com \\ ${ }^{3}$ Federal University of Viçosa, Forest Engineering Department, Viçosa, Minas Gerais, Brazil - venancioufv@ gmail.com \\ ${ }^{4}$ Federal University of Viçosa, Biology Department, Viçosa, Minas Gerais, Brazil - giniabt@ultimato.com.br
}

Received for publication: 27/02/2018 - Accepted for publication: 06/03/2019

\begin{abstract}
Resumo
Caracterização e estado de degradação das trilhas do Parque Nacional do Caparaó. Nos últimos anos observou-se um aumento expressivo da visitação nas unidades de conservação brasileiras. A presença de visitantes nesses locais pode ocasionar alterações no ambiente, originando alguns impactos indesejados. Assim, o presente trabalho objetivou caracterizar a visitação no Parque Nacional do Caparaó, bem como mapear as principais trilhas abertas ao público e diagnosticá-las quanto ao seu estado de degradação. Para definir as trilhas mais relevantes para este trabalho foram utilizados os seguintes critérios: demanda de visitação, intensidade dos impactos e zoneamento. Dessa maneira, as trilhas selecionadas tiveram seu perfil de elevação e demais atributos físicos obtidos com auxílio de um receptor GPS. Ao longo de cada percurso foram contabilizados os trechos erodidos, que consistiram no impacto predominante nos locais avaliados. A Trilha do Pico da Bandeira via Casa Queimada possui maior declividade e, embora receba uma quantidade de visitantes inferior à Trilha do Pico da Bandeira via Tronqueira, apresenta maior taxa de erosão. Esse resultado indica que, em determinados casos, a declividade pode contribuir de forma mais expressiva para o aumento dos processos erosivos que o número de visitantes.

Palavras-chave: unidades de conservação; uso público; erosão; Pico da Bandeira.
\end{abstract}

\begin{abstract}
A large increase in visitation has recently been observed in Brazilian protected areas. The presence of visitors can cause changes in the environment, generating certain unwanted impacts. Therefore, the objective of this study is to assess the visitation at Caparaó National Park, map the main trails open to the public, and determine their degree of degradation. To define the most relevant trails for this study, the following criteria were used: visitation demand, impact intensity, and zoning. The elevation profile and other physical attributes of the selected trails were obtained by GPS. Erosion was established as the predominant impact, and the length of eroded stretches on each trail was evaluated. The trail to Pico da Bandeira through Casa Queimada has a greater declivity, and, although it sees fewer visitors than the trail to Pico da Bandeira through Tronqueira, it shows a higher erosion rate. This result indicates that, in certain cases, the declivity can contribute more significantly to the increase in erosion than the number of visitors.
\end{abstract}

Keywords: protected areas; public use; erosion; Pico da Bandeira.

\section{INTRODUCTION}

Conservation units (UCs) are territorial spaces established by public authority with the purpose of protecting and maintaining the natural features of the area, including their environmental resources (BRASIL, 2000). The establishment of these units is one of the most important in situ conservation strategies for biological diversity and landscape abundance in Brazil (RYLANDS; BRANDON, 2005; REZENDE et al., 2011).

The National System of Conservation Units, established on July 18, 2000, by Federal Act 9,985, anticipates the existence of 12 UC categories, each subject to specific operating regulations: Ecological Station, Biological Reserve, National Park, Natural Monument, Wildlife Refuge, Environmental Protection Area, Area of Relevant Ecological Interest, National Forest, Extractive Reserve, Fauna Reserve, Sustainable Development Reserve, and Private Natural Heritage Reserve.

According to the National Registry of Conservation Units, the official database for the Ministry of Environment, there are currently 959 federal UCs in Brazil; they have a total area of $790,736 \mathrm{~km}^{2}$, which is equivalent to $9.3 \%$ of the country's land area (BRASIL, 2017).

However, these protected spaces are not "untouchable" or devoid of human activity (MEDEIROS et al., 2011). On the contrary, most of the UC categories allow for human activities, on a larger or smaller scale, inside these spaces. Tourism, for example, represents an important alternative for indirect exploration of their

FLORESTA, Curitiba, PR, v. 49, n. 4, p. 709 - 716, out/dez 2019.

Almeida, M. P. et.al.

ISSN eletrônico 1982-4688

DOI: $10.5380 /$ rf.v49 i4.58156 
environmental resources in order to generate economic options for the local population (FERRARO; HANAUER, 2014; SOUZA et al., 2018).

According to the Chico Mendes Institute for Biodiversity Conservation (ICMBIO) (ICMBIO, 2017a), the environmental agency of the Brazilian government responsible for managing all federal UCs in the country, among the 10 most-visited UCs in Brazil, 7 are National Parks, 1 is a National Forest, 1 is an Area of Environmental Protection, and 1 is an Extractive Reserve. Among all the existing UC categories, Brazilian National Parks accounted for $84.7 \%$ of the total visitation in 2016 , with 7,031,211 recorded visitors.

In the state of Minas Gerais (MG), there are eight National Parks, six of which are open for visitation: Cavernas do Peruaçu National Park, Grande Sertão Veredas National Park, Serra da Canastra National Park, Serra do Cipó National Park, Itatiaia National Park, and Caparaó National Park (ICMBIO, 2017b).

Caparaó National Park (PNC), established in 1961, is considered the locus of mountaineering in Brazil. According to the Brazilian Institute of Geography and Statistics (IBGE) (IBGE, 2015), it is home to 5 of the 15 highest peaks in all of the national territory, in particular Pico da Bandeira, which is the third highest point in Brazil. In 2015, PNC reported a record number of 54,548 visitors, which underscores the park's importance as a tourist destination (ICMBIO, 2017c).

Trails are used by visitors as one of their main means of leisure and recreation in UCs, either as their only means of access to the peak and waterfalls, or as the attraction itself, when having the experience of walking the trail is their main motive for visiting (ANDRADE, 2003).

However, the disorderly development of visitation, in addition to contributing to environmental degradation, can disfigure the local landscape, negatively affecting visitation motivated by the area's attractiveness (LADEIRA et al., 2007). In this context, it becomes necessary to acknowledge the negative impacts to these environments that can be caused by visitation and therefore promote adequate assessment and management of visitation (LOBO; SIMÕES, 2011).

Owing to increasing demand for activities related to public use at PNC, and considering the shortage of information facilitating the management of visitation impacts, the goal of this study is to characterize the visitation at PNC, map the main trails open to the public, and determine their degree of degradation.

\section{MATERIALS AND METHODS}

\section{Study area}

PNC, established on May 24, 1961, is located in the Atlantic Rainforest biome; approximately $79.4 \%$ of its territory is in the state of Espírito Santo (ES), and 20.6\% is in MG. The total territorial extension is 31,853.12 hectares (ICMBIO, 2017d).

The park has two entrances, one in São Raimundo da Pedra Menina (ES), a municipal district of Dores do Rio Preto, and the other in MG, in the city of Alto Caparaó, where the administrative center is also located. The distance in kilometers between the administrative center and the capitals in the southeast region are Vitória (230), Belo Horizonte (360), Rio de Janeiro (440), and São Paulo (770).

\section{Characterization of number of visitors}

The graphs related to the number of visitors were obtained using Microsoft Excel from secondary data available on the ICMBIO website (2017a, 2017c).

\section{Ranking of locations open for visitation}

The ranking of locations open for visitation is based on the methodology proposed by ICMBIO (2011), which consists of the most recently developed tools for the management of visitation impacts in the country and incorporates concepts from established methodologies, such as the Limit of Acceptable Change and Carrying Capacity, which were adapted to the reality of Brazilian UCs.

Initially, information was gathered from the management plan, academic studies, reports, and other documents related to visitation in PNC. Next, useful information for the subsequent stages of the study was identified. Analysis of the information contained in the documents was followed by field work to more thoroughly assess public use of the park.

The purpose of this stage was to draft a preliminary evaluation of the locations open for visitation so as to classify them according to their impact susceptibility. Then, the trails available to visitors in each sector of the park were listed and assessed according to three criteria: visitation demand, impact intensity (the value assigned to this criterion was multiplied by two), and zoning. Then, for each criterion, a score of 3, 2, or 1 was assigned (Table 1). 
Table 1. Outline of criteria and their scoring scales.

Tabela 1. Descrição dos critérios utilizados e sua respectiva escala de pontuação.

\begin{tabular}{|c|c|c|c|}
\hline Visitation demand & Impact intensity & Zoning & Score \\
\hline $\begin{array}{l}\text { High demand (more than } \\
70 \% \text { of visitors) }\end{array}$ & Visible impacts & Primitive zone & 3 \\
\hline $\begin{array}{l}\text { Regular demand ( } 40 \text { to } \\
70 \% \text { of visitors) }\end{array}$ & $\begin{array}{l}\text { Less evident or more } \\
\text { dispersed impacts }\end{array}$ & $\begin{array}{l}\text { Zone of } \\
\text { intensive use }\end{array}$ & 2 \\
\hline $\begin{array}{c}\text { Low demand (less than } \\
40 \% \text { of visitors) }\end{array}$ & No evidence of impacts & $\begin{array}{c}\text { Zone of } \\
\text { intensive use }\end{array}$ & 1 \\
\hline
\end{tabular}

Source: adapted from ICMBIO (2011).

The demand for visitation, as well as the condition of the observed impacts, was discussed and assessed in conjunction with the head of the UC, the coordinator of the research sector, and the author of this study. To establish the zone in which each trail is located, the zoning map of PNC, which is included in its management plan, was consulted.

The trails with the highest scores, i.e., those that demonstrated the highest susceptibility to impacts caused by visitation, were subjected to a complementary analysis of their visitation impacts.

\section{Trail mapping}

The trails were mapped using a GPS receiver, the Garmin 60CSx, which supplied the geographic coordinates, elevation profile, and path length of each trail. Subsequently, these spatial data were analyzed using a Geographic Information System based on the software GPS Trackmaker Pro and ArcGIS Desktop. To tabulate data and create graphics, Microsoft Excel was used.

\section{Complementary analysis of visitation impacts}

Among the impacts observed in the ranking of the locations open for visitation, erosion was the predominant impact, as shown by the frequency and extent of eroded stretches. Then, these stretches were measured with a tape measure (Zaas 50 metros), and the trail stretches that met at least one of the following criteria were considered: i) the presence of erosion in grooves or ravines $20 \mathrm{~cm}$ or more in depth and ii) exposure of roots and rocks on the trail bed.

\section{RESULTS}

\section{Characterization of number of visitors}

From 2010 to 2015, PNC exhibited an average growth of $11 \%$ in visitation, and all the National Parks (PARNAs) in Brazil had a growth rate of $12 \%$ in the same period. In 2014 and 2015, the growth rate of visitation to PNC was much larger than that observed in the other National Parks (Table 2).

Table 2. Visitation statistics for Caparaó National Park and other National Parks (PARNAs) in Brazil from 2010 to 2015 .

Tabela 2. Comparação das estatísticas de visitação no Parque Nacional do Caparaó e nos Parques Nacionais brasileiros entre 2010 e 2015 .

\begin{tabular}{lcccc}
\hline Year & Visitors at PNC & $\begin{array}{c}\text { Difference from } \\
\text { previous year at } \\
\text { PNC }\end{array}$ & Visitors at PARNAs & $\begin{array}{c}\text { Difference from } \\
\text { previous year at } \\
\text { PARNAs }\end{array}$ \\
\hline 2010 & 33,891 & - & $3,990,658$ & - \\
2011 & 29,057 & $-14 \%$ & $4,781,139$ & $20 \%$ \\
2012 & 33,366 & $15 \%$ & $5,431,319$ & $14 \%$ \\
2013 & 34,289 & $3 \%$ & $5,951,642$ & $10 \%$ \\
2014 & 43,377 & $27 \%$ & $6,594,870$ & $11 \%$ \\
2015 & 54,548 & $26 \%$ & $7,149,112$ & $8 \%$ \\
\hline
\end{tabular}

FLORESTA, Curitiba, PR, v. 49, n. 4, p. 709 - 716, out/dez 2019 
The visitation at PNC increased by $61 \%$ from 2010 to 2015 , a period in which the park recorded a record number of visitors in two consecutive years, with 54,548 visitors in 2015 ; this is an increase of $26 \%$ compared to the previous year.

PNC is typically accessed by its entrance in Alto Caparaó (MG), which welcomed a total of $77 \%$ of its visitors in 2015. Considering the total number of visitors between 2010 and 2015, it was established that 40,620 visitors used the entrance in Dores do Rio Preto (ES), whereas 187,908 (82\% of the total for that period) used the entrance in MG (Figure 1).

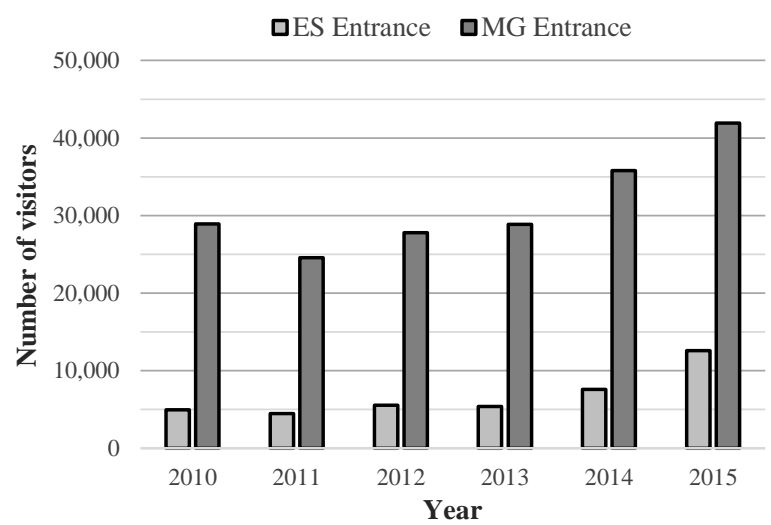

Figure 1. Comparison of the numbers of visitors entering PNC in ES and MG, 2010 to 2015.

Figura 1. Comparativo do número de visitantes nas duas portarias do Parque Nacional do Caparaó entre 2010 e 2015.

\section{Ranking of locations open for visitation}

PNC offers various attractions open to the public, both in the MG and ES portions of the park. The access trails to the trails were ranked, and those that received a score higher than 10 were considered highly susceptible to impacts (Table 3).

Table 3. Ranking results for locations open to visitors.

Tabela 3. Resultados da etapa de classificação dos locais abertos à visitação.

\begin{tabular}{lcccc}
\hline Access trail & Visitation demand & Impact intensity & Zoning & Total \\
\hline Pico da Bandeira via MG & $\mathbf{3}$ & $3 \times 2=\mathbf{6}$ & $\mathbf{2}$ & $\mathbf{1 1}$ \\
Pico da Bandeira via ES & $\mathbf{3}$ & $3 \times 2=\mathbf{6}$ & $\mathbf{2}$ & $\mathbf{1 1}$ \\
Pico do Calçado & $\mathbf{3}$ & $3 \times 2=\mathbf{6}$ & $\mathbf{1}$ & $\mathbf{1 0}$ \\
Vale Verde & $\mathbf{3}$ & $3 \times 2=\mathbf{6}$ & $\mathbf{1}$ & $\mathbf{1 0}$ \\
Cachoeira Sete Pilões & $\mathbf{3}$ & $2 \times 2=\mathbf{4}$ & $\mathbf{1}$ & $\mathbf{8}$ \\
Vale Encantado & $\mathbf{2}$ & $2 \times 2=\mathbf{4}$ & $\mathbf{1}$ & $\mathbf{7}$ \\
Cachoeira Bonita & $\mathbf{2}$ & $2 \times 2=\mathbf{4}$ & $\mathbf{1}$ & $\mathbf{7}$ \\
Pedra Duas Irmãs & $\mathbf{1}$ & $2 \times 2=\mathbf{4}$ & $\mathbf{1}$ & $\mathbf{6}$ \\
Gruta do Jacu & $\mathbf{1}$ & $2 \times 2=\mathbf{4}$ & $\mathbf{1}$ & $\mathbf{6}$ \\
Cachoeira do Aurélio & $\mathbf{2}$ & $1 \times 2=\mathbf{2}$ & $\mathbf{1}$ & $\mathbf{5}$ \\
Cachoeira da Farofa & $\mathbf{2}$ & $1 \times 2=\mathbf{2}$ & $\mathbf{1}$ & $\mathbf{5}$ \\
\hline
\end{tabular}

The two access trails to Pico da Bandeira, via Tronqueira and via Casa Queimada, have sections in the intensive use zone (IUZ) and extensive use zone (EUZ). All the other trails are located entirely in the IUZ. The main purpose of the IUZ is to offer the necessary conditions for adequate development of visitation and to house the visitor center and other support infrastructure, whereas the EUZ is intended to maintain a minimally anthropized landscape, although controlled entry of visitors is allowed.

Note that Pico do Calçado is located on the access trail to Pico da Bandeira, i.e., the trail to Pico do Calçado coincides with the trail to Pico da Bandeira via Casa Queimada (Figure 2). Thus, the two access trails to Pico da Bandeira (via Tronqueira and via Casa Queimada), as well as the access trail to Pico do Calçado, were selected as the object of study in subsequent stages. 


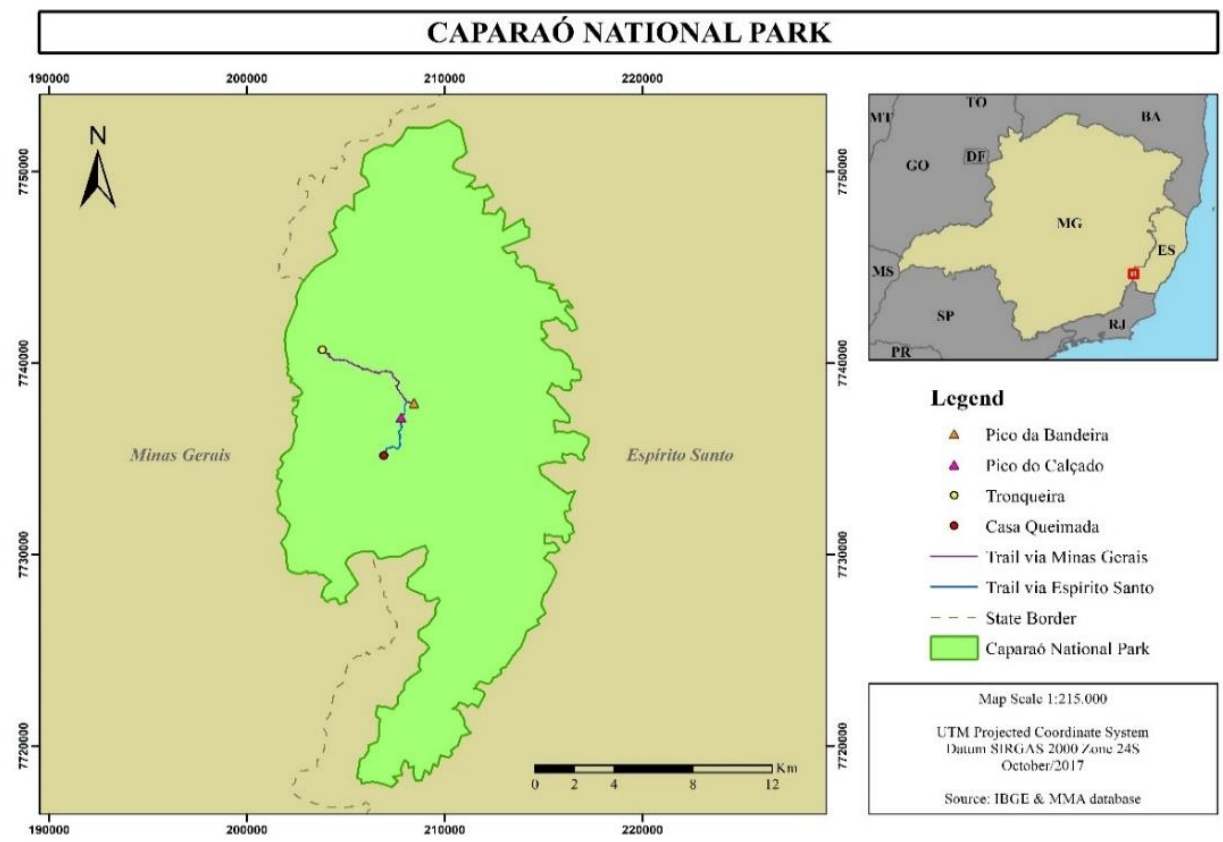

Figure 2. Location of PNC and its main trails.

Figura 2. Localização do Parque Nacional do Caparaó e suas principais trilhas.

\section{Trail mapping}

Using the data collected in the field, a specifications sheet was designed (Table 4) that provides the main physical attributes and locations of both trails.

Table 4. Specifications of the access trails to Pico da Bandeira.

Tabela 4. Ficha técnica das trilhas de acesso ao Pico da Bandeira.

\begin{tabular}{|c|}
\hline ACCESS TRAIL TO PICO DA BANDEIRA VIA TRONQUEIRA \\
\hline Starting Point (Tronqueira) \\
\hline Geographic coordinates: $20^{\circ} 24^{\prime} 35.82^{\prime \prime} \mathrm{S}, 41^{\circ} 50^{\prime} 12.52^{\prime \prime} \mathrm{W}$ \\
\hline Altitude: $1,972 \mathrm{~m}$ \\
\hline End Point (Pico da Bandeira) \\
\hline Geographic coordinates: $20^{\circ} 26^{\prime} 05.31^{\prime \prime} \mathrm{S}, 41^{\circ} 47^{\prime} 45.16^{\prime \prime} \mathrm{W}$ \\
\hline Altitude: $2,892 \mathrm{~m}$ \\
\hline Total course \\
\hline Extension: $6,648 \mathrm{~m}$ \\
\hline Estimated duration: $4 \mathrm{~h}$ and $15 \mathrm{~min}$ (outbound) \\
\hline $2 \mathrm{~h}$ and $45 \mathrm{~min}$ (inbound) \\
\hline ACCESS TRAIL TO PICO DA BANDEIRA VIA CASA QUEIMADA \\
\hline Starting point (Casa Queimada) \\
\hline Geographic coordinates: $20^{\circ} 27^{\prime} 27.80^{\prime \prime} \mathrm{S}, 41^{\circ} 48^{\prime} 30.81^{\prime \prime W}$ \\
\hline Altitude: $2,193 \mathrm{~m}$ \\
\hline End Point (Pico da Bandeira) \\
\hline Geographic coordinates: $20^{\circ} 26^{\prime} 05.31^{\prime \prime} \mathrm{S}, 41^{\circ} 47^{\prime} 45.16^{\prime \prime} \mathrm{W}$ \\
\hline Altitude: $2,892 \mathrm{~m}$ \\
\hline Total course \\
\hline Extension: $4,317 \mathrm{~m}$ \\
\hline Estimated duration: $3 \mathrm{~h}$ and $45 \mathrm{~min}$ (outbound) \\
\hline
\end{tabular}

FLORESTA, Curitiba, PR, v. 49, n. 4, p. 709 - 716, out/dez 2019.

Almeida, M. P. et.al.

ISSN eletrônico 1982-4688

DOI: $10.5380 /$ rf.v49 i4.58156 


\section{Complementary analysis of visitation impacts}

Both trails show several signs of degradation, where the presence of erosion in grooves or ravines is the predominant impact.

The trail to Pico da Bandeira via Casa Queimada (ES) is shorter, but shows a steeper declivity. The trail in ES exhibits a declivity of over $20 \%$ (which corresponds to the average declivity of the two trails) along $44 \%$ of its length, whereas the trail in MG has the same declivity on $31 \%$ of its length. Figure 3 shows the elevation profiles of both trails.

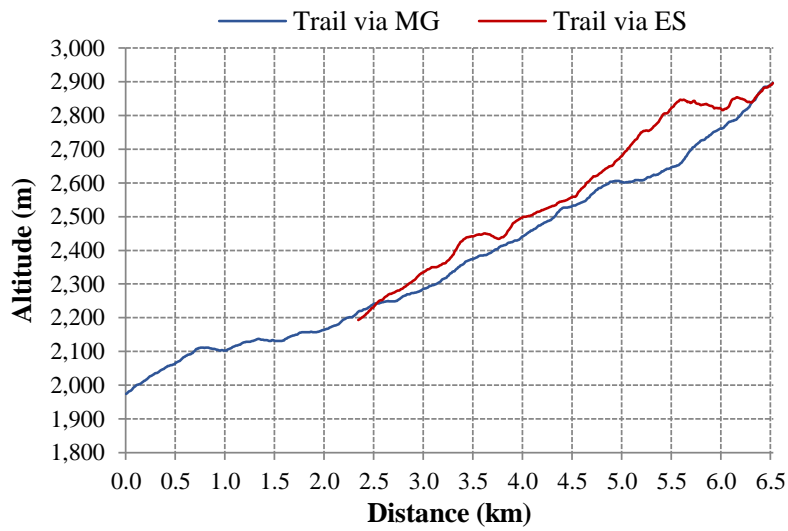

Figure 3. Elevation profile for the access trails to Pico da Bandeira.

Figura 3. Perfil de elevação das trilhas de acesso ao Pico da Bandeira.

Even though visitation is more intense on the side of the park located in MG, the access trail to Pico da Bandeira via Casa Queimada appeared to be more degraded, with a total of $693 \mathrm{~m}$ of eroded stretches, which corresponds to $16 \%$ of its total length. By contrast, the trail that starts at Tronqueira showed $643 \mathrm{~m}$ of eroded stretches, which is equivalent to $10 \%$ of its total length (Table 5).

Table 5. Physical attributes and impact extent of the access trails to Pico da Bandeira.

Tabela 5. Atributos físicos e extensão dos impactos nas trilhas de acesso ao Pico da Bandeira.

\begin{tabular}{lcc}
\hline Attribute & Trail via MG & Trail via ES \\
\hline Total length of the trail & $6,648 \mathrm{~m}$ & $4,317 \mathrm{~m}$ \\
Accumulated altitude difference & $920 \mathrm{~m}$ & $699 \mathrm{~m}$ \\
Length of stretches with declivity higher than $20 \%$ & $2,060 \mathrm{~m}$ & $1,915 \mathrm{~m}$ \\
Length of eroded stretches & $643 \mathrm{~m}$ & $693 \mathrm{~m}$ \\
\hline
\end{tabular}

\section{DISCUSSION}

\section{Characterization of number of visitors}

Several factors help explain the increase in visitation demand, such as the promotion of the park on the media and social networks, as well as improvements in the quality of tourist services in the area. On the other hand, the location of PNC, which is far from large urban centers, can be considered an obstacle to an even greater increase in visitor numbers.

The disparity in the number of visitors at the two entrances (approximately $80 \%$ in MG and 20\% in ES) is due in part to the later implementation of the entrance in Dores do Rio Preto (ES), which according to Massini et al. (2015) was opened in the late 1990s.

\section{Trail mapping and complementary analysis of visitation impacts}

The opening of a secondary route along the main trail, because it causes loss of vegetation, promotes changes in the physical properties of the soil and can favor the establishment of new erosive processes (VASHCHENKO et al., 2007). These results are consistent with the report of Marion and Cole (1996), who suggested that the soil in protected natural areas is effected mainly by trampling due to the loss of litterfall, soil compaction, lower infiltration, increases in superficial drainage, and consequently, worsening erosion.

Erosive processes tend to be established predominantly in areas with high declivity and intense use, as suggested by Cogo et al. (2003), Pereira et al. (2003), and Vashchenko et al. (2008). In addition to these factors, 
Gualtieri-Pinto et al. (2008) noted the physicochemical properties of the soil as a factor that can affect the establishment of erosive processes.

In the present study, the increase in erosion along the trails has been shown to depend more on the declivity than on the intensity of use. However, variables such as soil type, declivity, and intensity of use do not act independently, but have complex relationships and affect the trails in different ways.

Thus, further studies are recommended that consider other variables, such as soil type, and correlate them with the declivity and use intensity in order to better understand the erosion phenomena on the trails in PNC, and consequently to assist the UC management in choosing more suitable management strategies for each trail.

Among the trail management strategies that could be adopted to mitigate erosion, the installation of containment barriers according to Hesselbarth (2009) is the most relevant, as they reduce the velocity of superficial drainage and consequently the transport of soil particles. Additionally, replenishing the litterfall on the trail can contribute in many ways, such as minimizing soil compaction by trampling. On the most critical stretches, where erosion can limit the movement and safety of visitors, alteration of the original path becomes a suitable strategy.

\section{CONCLUSION}

- From 2010 to 2015 , the number of visitors to PNC increased by $61 \%$, and most of the visitors entered through the entrance in MG. In the same period, visitation to all Brazilian National Parks combined showed an increase of $79 \%$.

- Even though the trail to Pico da Bandeira that starts in Casa Queimada (ES) welcomed fewer visitors than the trail that begins in Tronqueira (MG), it showed more extensive and severe erosive processes, as well as a higher declivity and shorter length.

- Therefore, the results presented in this study indicate that the increase in erosive processes along the trails is more strongly associated with the declivity of the terrain than with the number of visitors.

\section{ACKNOWLEDGMENTS}

The Coordination for the Improvement of Higher Level Personnel (CAPES) is acknowledged for awarding the first author a scholarship during the realization of this study.

\section{REFERENCES}

ANDRADE, W. J. Implantação e manejo de trilhas. In: MITRAUD, S. (Org.). Manual de ecoturismo de base comunitária: ferramentas para um planejamento responsável. Brasília: WWF Brasil, 2003. 470 p.

BRASIL. Ministério do Meio Ambiente. SNUC - Sistema Nacional de Unidades de Conservação da Natureza: Lei $n^{\circ}$ 9.985, de 18 de julho de 2000; Decreto $n^{\circ} 4.340$, de 22 de agosto de 2002; Decreto $n^{\circ} 5.746$, de 5 de abril de 2006. PNAP - Plano Estratégico Nacional de Áreas Protegidas: Decreto no 5.758, de 13 de abril de 2006. Brasília: MMA, 2011. 76 p.

BRASIL. Ministério do Meio Ambiente. Dados Consolidados. 2017. Available at: <http://www.mma.gov.br/areas-protegidas/cadastro-nacional-de-ucs/dados-consolidados>. Accessed: Nov. 18, 2017.

COGO N. P.; LEVIEN R.; SCHWARZ R. A. Perdas de solo e água por erosão hídrica influenciadas por métodos de preparo, classes de declive e níveis de fertilidade do solo. Revista Brasileira de Ciência do Solo, Viçosa, v. 27, n. 4, p. 743-753, 2003. DOI: http://dx.doi.org/10.1590/S0100-06832003000400019

FERRARO, P. J.; HANAUER, M. M. Quantifying causal mechanisms to determine how protected areas affect poverty through changes in ecosystem services and infrastructure. Proceedings of the National Academy of Sciences, v. 111, n. 11, p. 4332-4337, 2014. DOI: https://doi.org/10.1073/pnas.1307712111

GUALTIERI-PINTO, L.; OLIVEIRA, F. F.; ALMEIDA-ANDRADE, M.; PEDROSA, H. F.; SANTANA, W. A.; FIGUEIREDO, M. A. Atividade erosiva em trilhas de unidades de conservação: estudo de caso no Parque Nacional da Serra do Cipó, Minas Gerais, Brasil. E-scientia, Belo Horizonte, v. 1, n. 1, 2008.

HESSELBARTH, W.; VACHOWSKI, B.; DAVIES, M. A. Manual de construção e manutenção de trilhas. São Paulo: Governo do Estado de São Paulo, Secretaria do Meio Ambiente, 2009. 172 p.

INSTITUTO BRASILEIRO DE GEOGRAFIA E ESTATÍSTICA - IBGE. Anuário Estatístico do Brasil de 2015. Anu. estat. Brasil, Rio de Janeiro, v. 75, 2015. 
INSTITUTO CHICO MENDES DE CONSERVAÇÃO DA BIODIVERSIDADE - ICMBIO. Roteiro metodológico para manejo de impactos da visitação. Brasília: ICMBIO, 2011. 88 p.

INSTITUTO CHICO MENDES DE CONSERVAÇÃO DA BIODIVERSIDADE - ICMBIO. Dados de Visitação (2007-2016). 2017a. Available at: <http://www.icmbio.gov.br/portal/ultimas-noticias/20-geral/8711-crescenumero-de-visitantes-nos-parques-nacionais $>$. Accessed: Dec. 10, 2017.

INSTITUTO CHICO MENDES DE CONSERVAÇÃO DA BIODIVERSIDADE - ICMBIO. Unidades Abertas à Visitação. 2017b. Available at: 〈http://www.icmbio.gov.br/portal/visitacao1/unidades-abertas-a-visitacao〉. Accessed: Dec. 12, 2017.

INSTITUTO CHICO MENDES DE CONSERVAÇÃO DA BIODIVERSIDADE - ICMBIO. Visitação (20102015). 2017c. Available at: <http://www.icmbio.gov.br/parnacaparao/destaques/45-titulo.html〉. Accessed: Oct. 21, 2017.

INSTITUTO CHICO MENDES DE CONSERVAÇÃO DA BIODIVERSIDADE - ICMBIO. Plano de manejo: Parque Nacional do Caparaó. 2017d. Available at: 〈http://www.icmbio.gov.br/parnacaparao/plano-de-manejo>. Accessed: Oct. 15, 2017.

LADEIRA, A. S.; RIBEIRO, G. A.; DIAS, H. C. T.; SCHAEFER, C. E. G. R.; FERNANDES-FILHO, E.; OLIVEIRA-FILHO, A. T. O perfil dos visitantes do Parque Estadual do Ibitipoca, Lima Duarte, MG. Revista Árvore, Viçosa, v. 31, n. 6, p. 1091-1098, 2007. DOI: http://dx.doi.org/10.1590/S0100-67622007000600014

LOBO, A. C.; SIMÕES, L. L. (Org.). Manual de monitoramento e gestão dos impactos da visitação em unidades de conservação. São Paulo: Secretaria do Meio Ambiente/WWF-Brasil, 2011. 78 p.

MARION, J. L.; COLE, D. N. Spatial and temporal variation in soil and vegetation impacts on campsites. Ecological Applications, v. 6, n. 2, p. 520-530, 1996. DOI: http://dx.doi.org/10.2307/2269388

MASSINI, V. S.; BEDIM, B. P.; FONSECA-FILHO, R. E. O turismo em Patrimônio da Penha (ES) e suas interfaces com o Parque Nacional do Caparaó. Revista Brasileira de Ecoturismo, São Paulo, v. 7, n. 4, p. 715734, 2015.

MEDEIROS, R.; YOUNG, C. E. F.; PAVESE, H. B.; ARAÚJO, F. F. S. Contribuição das unidades de conservação brasileiras para a economia nacional: Sumário Executivo. Brasília: UNEP-WCMC, 2011. 44 p.

PEREIRA, S. B.; PRUSKI, F. F.; SILVA, D. D.; MATOS, A. T. Desprendimento e arraste do solo pelo escoamento superficial. Revista Brasileira de Engenharia Agrícola e Ambiental, Campina Grande, v. 7, n. 3, p. 423-429, 2003. DOI: http://dx.doi.org/10.1590/S1415-43662003000300003

REZENDE, R. A.; PRADO-FILHO, J. F.; SOBREIRA, F. G. Análise temporal da flora nativa no entorno de unidades de conservação - APA Cachoeira das Andorinhas e FLOE Uaimii, Ouro Preto, MG. Revista Árvore, Viçosa, v. 35, n. 3, p. 435-443, 2011. DOI: http://dx.doi.org/10.1590/S0100-67622011000300007

RYLANDS, A. B.; BRANDON, K. Brazilian protected areas. Conservation Biology, v. 19, n. 3, p. 612-618, 2005. DOI: http://dx.doi.org/10.1111/j.1523-1739.2005.00711.x

SOUZA, T. V. S. B.; THAPA, B.; RODRIGUES, C. G. O.; IMORI, D. Economic impacts of tourism in protected areas of Brazil. Journal of Sustainable Tourism, v. 26, 2018. DOI: https://doi.org/10.1080/09669582.2017.1408633

VASHCHENKO, Y.; FAVARETTO, N.; BIONDI, D. Fragilidade ambiental nos picos Camacuã, Camapuã e Tucum, Campina Grande do Sul, PR. Floresta, Curitiba, v. 37, n. 2, 2007. DOI: http://dx.doi.org/10.5380/rf.v37i2.8650

VASHCHENKO, Y.; BIONDI, D.; FAVARETTO, N. Erosão causada pela prática do montanhismo na trilha para os picos Camapuã e Tucum - Campina Grande do Sul (PR). Floresta, Curitiba, v. 38, n. 1, 2008. DOI: http://dx.doi.org/10.5380/rf.v38i1.11028 